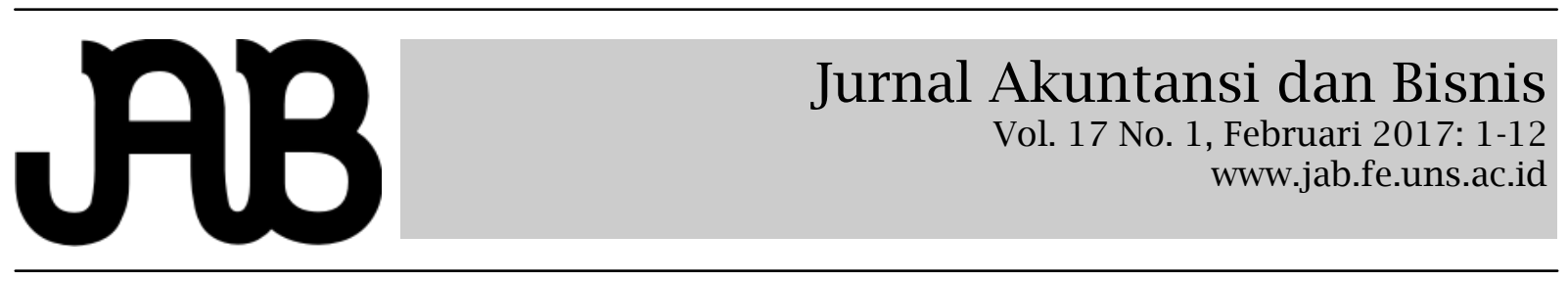

\title{
PERSEPSI MAHASISWA DALAM MENGURANGI FRAUD AKADEMIK: WHISTLEBLOWING SISTEM
}

NASHIROTUN NISA NURHARJANTI (nnn122@ums.ac.id)

Program Studi Akuntansi, Fakultas Ekonomika dan Bisnis, Universitas Muhammadiyah Surakarta

\begin{abstract}
A B S T R A C T
The purpose of this research is to explain the whistleblowing system in reducing academic fraud, to explain academic fraud among students that often done to reduce the level of cheating and to give a process of whistleblowing system. This study usedqualitative method. Respondents of this research is member of HIMATANSI Muhammadiyah Surakarta University. The result of this research shows that academic fraud can be reduced by applying whistleblowing system because it has many benefits. One of them is the college environment could be more conducive, the quality of learning could be better so and boost students compliance at campus. Students perception on the whistleblowing system can be applied when there are: (1) the role of students in reported fraud that happened on campus, (2) the role of students in socialization the importance of whistleblowing system, (3) reported when discover their situation that lead to the act of academic fraud and (4) help in the process of monitoring whether this system work. The role of the student can reduce the act of academic fraud and can produce graduates who have ethical personal characteristic and have the courage to reveal cheating.
\end{abstract}

Keywords : academic fraud, whistleblowing system, student, qualitative method

Tujuan penelitian ini adalah untuk menjelaskan implementasi sistem whistleblowing dalam mengurangi kecurangan akademik, untuk menjelaskan kecurangan akademik yang sering dilakukan dikalangan mahasiswa agar dapat dikurangi tingkat kecurangan tersebut, dan untuk memberikan gambaran proses kerja whistleblowing sistem. Penelitian ini menggunakan pendekatan kualitatif. Responden yang digunakan dalam penelitian ini adalah mahasiswa HIMATANSI Universitas $\mathrm{Mu}$ hammadiyah Surakarta. Hasil dari penelitian ini adalah kecurangan yang terjadi dapat dikurangi dengan menerapkan whistleblowing sistem, karena whistleblowing sistem ini mempunyai banyak manfaat seperti kondisi kampus menjadi lebih kondusif dan kualitas pembelajaran menjadi lebih baik. Hal ini menyebabkan output yang dihasilkan juga lebih baik serta meningkatkan kepatuhan mahasiswa terhadap peraturan yang diberlakukan di lingkungan kampus. Persepsi mahasiswa mengenai sistem whistleblowing dapat diterapkan ketika ada: (1) peranan mahasiswa dalam melaporkan tindakan kecurangan yang terjadi di kampus, (2) peranan mahasiswa membantu dalam proses sosialisasi akan pentingnya whistleblowing sistem, (3) melaporkan apabila menemukan situasi yang mengarah kepada tindakan kecurangan akademik dan (4) membantu dalam proses pemantauan apakah sistem ini berjalan. Sehingga diharapkan peranan mahasiswa ini dapat mengurangi tindakan kecurangan akademik dan dapat menghasilkan lulusan yang mempunyai karakteristik pribadi yang beretika serta mempunyai keberanian untuk mengungkap kecurangan.

Kata kunci : kecurangan akademik, whistleblowing sistem, mahasiswa, pendekatan kualitatif.

\section{PENDAHULUAN}

Kecurangan (fraud) merupakan tindakan yang dilakukan karena ada kesempatan, peluang, tekanan dan pembenaran akan apa yang dilakukan. Tindakan ini bisa terjadi dibeberapa situasi dan tempat, seperti di lingkungan paling bawah yaitu keluarga dimana keluarga merupakan organisasi paling dasar dalam pembentukan kebiasaan individu dalam bersikap, kemudian sekolah atau universitas sebagai tempat kedua setelah individu keluar untuk berinteraksi dengan individu lainnya sampai ke level yang teratas yaitu organisasi atau perusahaan dimana individu tersebut bekerja. Beberapa 
level tersebut merupakan kondisi yang bisa menciptakan situasi yang positif ataupun negatif. Kondisi yang positif atau negatif ini bisa terjadi karena ada niat. Perilaku yang dimaksud disini adalah niat untuk melaporkan tindakan kecurangan yang dilakukan seseorang yang bermaksud untuk merugikan organisasi dimana dia berada. Tindakan ini bisa disebut dengan istilah whistleblower.

Peranan whistleblower sangat diperlukan karena memberikan manfaat seperti: meminimalisasi pengeluaran yang mengakibatkan cost menjadi besar, organisasi menjadi memiliki kemampuan yang lebih baik dalam beradaptasi terkait peraturan yang berkaitan dengan GCG (Good Corporate Governance), lingkungan menjadi lebih stabil dan aman karena setiap gangguan negatif cepat terdeteksi, pengelolaan organisasi menjadi efisien karena sistem pengendali berfungsi dengan baik, dan perkembangan moral dalam lingkungan organsasi akan menjadi lebih baik (Mamoer et al., 2007). Sedangkan kata pengadu (whistleblower) dikenal di kalangan masyarakat ketika ada permasalahan. Perwira Tinggi Polri yang saat itu mempunyai jabatan sebagai Kepala Badan Reserse dan Kriminal (BARESKRIM) bernama Komisaris Jenderal Susno Duadji yang bertindak sebagai whistleblower dan melaporkan mafia pajak di instansinya. Kasus ini mengkaitkan pegawai Direktorat Jenderal Pajak bernama Gayus Tambunan yang terlibat dalam kasus pencucian uang dan korupsi.

Kasus lain yang terjadi di Kepolisian adalah kasus simulator Surat Ijin Mengemudi (SIM) yang mengkaitkan perwira tinggi Polri bernama Djoko Susilo dan teman-tamannya, kemudian terdapat seorang whistleblower yang berusaha menceritakan skandal yang terjadi di tempatnya bekerja. Whistleblower tersebut adalah Agus Condro yang merupakan anggota DPR RI periode 1999-2004. Beliau melaporkan telah terjadi skandal berupa penyuapan ketika pemilihan Deputi Gubernur Senior Bank Indonesia di tahun 2004 yang melibatkan dirinya dan beberapa koleganya di DPR RI. Kondisi diatas menjadikan whistleblower sistem apabila diterapkan mempunyai dampak yang positif. Contoh yang sudah menerapkan whistleblower adalah kementerian keuangan. Kementerian keuangan menggunakan sebuah aplikasi yang diberinama Wise. Sistem kerja dari Wise ini terintegrasi, jadi ada yang langsung ditangani oleh pusat (Inspektorat) dan ada yang diserahkan ke unit, namun unit hanya bisa melihat sebatas apa yang menjadi wewenangnya sehingga data yang diterima tidak utuh. Cara kerja sistem Wise ini juga dimonitor oleh IBI dan satu hal yang membuat pelapor memiliki keberanian adalah adanya jaminan. Sistem Wise ini sudah ada peraturan yang menguatkan yaitu PMK Nomor 103/ PMK.09/2010 tentang Tata Cara Pengelolaan dan Tindak Lanjut Pelaporan Pelanggaran (Whistleblowing) di Lingkungan Kementerian Keuangan dan KMK Nomor 149/KMK.09/2011 tentang Tata Cara Pengelolaan dan Tindak Lanjut Pelaporan Pelanggaran (Whistleblowing) Serta Tata Cara Pelaporan dan Publikasi Pelaksanaan Pengelolaan Pelaporan Pelanggaran (Whistleblowing) di Lingkungan Kementerian Keuangan. Selain peraturan tersebut, tim IBI sudah memberikan pilihan kepada pelapor agar pihak pelapor merasa aman. Hal ini terkait dengan tempat bertemu, dokumentasi tidak akan dilakukan dan apabila pelapor tidak ingin bertemu dapat melalui pesan, telepon, sms, atau media apapun yang membuat pelapor aman dan nyaman. Tim akan menghubungi pelapor untuk mengkonfirmasi laporan lebih lanjut. Lalu menentukan apakah pengaduannya patut dilanjutkan atau hanya mengarah ke fitnah/pengaduan kosong.

Langkah Kementerian Keuangan ini tentunya merupakan suatu langkah yang bisa dijadikan contoh untuk diaplikasikan di Perguruan Tinggi karena dalam Perguruan Tinggi indikasi kecurangan akademik yang dilakukan oleh mahasiswa masih sering terjadi sehingga sistem whistleblowing ini dapat mengurangi tindakan kecurangan. Namun menjadi seorang whistlebower bukan merupakan pilhan yang mudah meskipun sudah diberikan jaminan keamanan. Penerapan 
whistleblowing di perguruan tinggi ini dapat memberikan keberanian untuk mengungkapkan tindakan yang mengindikasikan kecurangan sehingga lingkungan yang ada di kampus menjadi lingkungan yang bebas dari istilah 3M/ Plagiarisme (mencontek, menyalin, meniru), menitip presensi, mengubah nilai akhir, dan memanipulasi data ketika skripsi. Kecurangan akademik menunjukkan perilaku yang tidak etis bagi mahasiswa akuntansi. Padahal profesi akuntan merupakan suatu profesi yang menuntut profesionalisme dan kejujuran. Hal ini sejalan dengan penelitian dengan topik whistleblowing dilakukan oleh Elias (2008) yang meneliti perilaku mahasiswa pengauditan di US perihal whistleblowing. Penelitian Zhang, Chiu, dan Wei (2009) yang mempunyai tujuan untuk menyarankan whistleblowing judg ment, positive mood dan organizational ethical culture sebagai estimasi niat dalam menjalankan whistleblowing. Selain itu penelitian whistleblowing pernah dilakukan oleh Hwang, Staley, Te Chen, \& Lan (2008) yang memiliki tujuan untuk mengetahui akibat dari culture pada niat akuntan dan auditor professional saat ini dan dimasa yang akan datang untuk menjadi whistleblower pada sosial budaya Cina. Hasil dari penelitian ini menunjukkan kebanyakan dari responden mengakui bahwa pengertian moralitas secara umum merupakan suatu hal yang penting untuk mendorong whistleblowing, yang dilakukan dengan cara mematuhi peraturan organisasi. Selain itu, penelitian ini menemukan bahwa guanxi, takut terhadap ancaman dari yang terlapor dan takut terhadap berita di media yang mengakibatkan seseorang akan berfikir ulang untuk menjadi whistleblowing di lingkungan masyarakat Cina. Sedangkan menurut penelitian yang dilakukan oleh Sulistomo (2012) menunjukkan bahwa anggapan terkait norma subyektif, sikap dan anggapan tentang kendali perilaku berpengaruh signifikan positif terhadap niat mahasiswa akuntansi dalam mengungkap kecurangan. Hal ini mengindikasikan bahwa jika adanya lingkungan atau budaya yang mendukung dan respon positif dalam mengungkapkan kecurangan akan mendorong mahasiswa akuntansi untuk mempunyai niat dalam mengungkap kecurangan. Contohkecurangan yang terjadi di kalangan mahasiswa adalah plagiarism. Dalam Penelitian Arista (2015) mengatakan bahwa plagiarime yang terjadi di lingkungan mahasiswa dikarenakan adanya budaya dosen dalam mengajar, akses informasi yang mudah, kurangnya pengetahuan tentang plagiarisme, kurangnya monitoring, bertujuan mencari nilai dan IPK, serta faktor ekonomi. Sedangkan menurut Zainur (2012) plagiarisme terjadi dikarenakan adanya perkembangan teknologi dan beban tugas dari dosen. Kondisi-kondsi yang telah dicontohkan diatas memberikan gambaran bahwa perilaku pengungkapan bisa dilakukan oleh mahasiswa dengan adanya niat akan tetapi terkadang niat tersebut sudah ada namun terbentur dengan ada- nya rasa takut dan tidak aman sehingga diperlukan jaminan keamanan dan kerahasiaan. Jaminan tersebut dapat dibangun dengan setiap fakultas membuat sistem terkait dengan whistle blow er. Sistem ini nantinya diharapkan mengurangi tingkat kecurangan dikalangan mahasiswa, selain itu sistem whistleblow ing ini juga mampu melatih profesionalisme seorang mahasiswa agar terhindar dari kecurangan akademik.

\section{TINJAUAN PUSTAKA DAN PENGEM- BANGAN HIPOTESIS}

Menurut Lembaga Perlindungan Saksi dan Korban (LPSK, 2011), whistleblowing diartikan sebagai perilaku mengungkapkan atau melaporkan tindak pidana atau tindakan yang dianggap ilegal di perusahaan atau orang lain berada, kepada otoritas internal organisasi atau kepada publik seperti media massa atau lembaga pemantau publik. Pelaporan tersebut tidak selalu didasari niat yang baik dari sang pelapor, tetapi mempunyai maksud untuk melaporkan kejahatan atau penyelewengan yang diketahuinya. Dalam kasus ini, orang yang melaporkan kecurangan atau penyelewengan disebut sebagai whistleblower. Whistleblowing merupakan 
suatu istilah yang muncul sejak adanya Sarbanes Oxley Act 2002 (SOX) di Amerika Serikat yang dapat mendorong para pegawai dari perusahaan untuk melakukan pelaporan atas pelanggaran yang terjadi tanpa ada rasa takut terhadap pihak yang dilaporkan. Di Indonesia, Pedoman Sistem Pelaporan dan Pelanggaran atau Whistleblowing System diterbitkan oleh Komite Nasional Kebijakan Governance (KNKG) pada tanggal 10 November 2008.

Tindakan pencegahan fraud selain dapat dilakukan dengan melakukan proses audit pada perusahaan juga dapat menggunakan whistleblowing sistem. Selain itu deteksi dini (early warning system) terhadap kemungkinan terjadinya suatu pelanggaran juga dapat digunakan. Hal ini dikarenakan early warning system mempunyai tujuan agar dapat ditangani secara internal sebelum masalah ini diketahui oleh publik. Manfaat whistleblowing ini adalah dapat mencegah fraud, membuat seseorang akan berfikir ulang ketika akan melakukan pelanggaran karena ketika melakukan pelanggaran ada pihak pelapor yang melaporkan tindakan yang tidak beretika sehingga bisa dikatakan sistem pelaporan berjalan efektif (Tuanakotta, 2007).

Whistleblowing merupakan suatu langkah yang kompleks dan melibatkan faktor pribadi dan organisasi (Mustapha \& Siaw, 2012). Whistleblower adalah seseorang yang mengungkap atau melaporkan tindak pelanggaran dan kecurangan (whistleblowing). Pada dasarnya whistleblower adalah karyawan dari organisasi atau perusahaan tempat ia bekerja. Apabila diaplikasikan dalam objek penelitian ini maka yang berperan sebagai whistleblower adalah mahasiswa dari program studi atau tempat dimana ia belajar. Whistleblower biasanya mempunyai data atau bukti yang memadai terkait tindakan yang melawan hukum tersebut. Peran whistleblower sangatlah penting dalam mengungkap suatu tindakan melawan hukum di dalam internal organisasi ataupun mengungkap kecurangan akademik yang dilakukan oleh mahasiswa.

Peran

whistleblower

adalah pengawasan kinerja organisasi dan mahasiswa di dalam proses belajar mengajar. Hal ini dikarenakan whistleblower dapat diperankan oleh siapa saja yang mengetahui tindak kecurangan dalam organisasi atau perguruan tinggi. Namun, banyak orang yang kurang memiliki keberanian untuk mengadukan tindak kecurangan, karena adanya resiko yang harus dihadapi, bahkan sulit dihindari dan beberapa dari mereka lebih memilih untuk tidak melakukan pengaduan meskipun rekan sekerja atau rekan satu kelas melakukan tindakan kecurangan. Bentuk-bentuk resiko yang dihadapi adalah mulai dari diasingkan oleh teman satu kelas sampai ancaman yang mengakibatkan pihak pelapor merasa khawatir akan dirinya sendiri karena bisa berimbas ketika mencari pekerjaan karena terlapor akan balas dendam terhadap pelapor. Namun saat ini jaminan keamanan dan perlindungan hukum terhadap whistleblower sudah ada sejak tahun 2006 dengan lahirnya UU 13/2006 tentang Perlindungan Saksi dan Korban. Hal tersebut merupakan salah satu pendorong atau motivasi seseorang untuk menjadi whistleblower.

Seorang whistleblower dalam upaya mengungkap suatu tindak pelanggaran dan kecurangan, baik di perusahaan, lembaga pemerintahan dan lembaga pendidikan memang dapat dilatarbelakangi berbagai motivasi, seperti pembalasan dendam ingin "menjatuhkan" perusahaan tempatnya bekerja atau teman satu kelas, mencari "selamat", atau niat untuk menciptakan lingkungan perusahaan dan lingkungan perguruan tinggi menjadi tempat yang lebih baik dan lebih beretika. Dengan kata lain whistleblower memiliki motivasi pilihan etis yang kuat untuk berani mengungkap skandal kejahatan terhadap publik. Beberapa penelitiaan terdahulu telah meneliti mengenai whistleblowing. Elias (2008) menyimpulkan bahwa umumnya para siswa merasa bahwa tindakan whistleblowing diperlukan dalam mengungkapkan kasus kecurangan, meskipun mereka cenderung tidak ingin melakukan tindakan whistleblowing karena tingginya resiko seperti pembalasan dan 
sulitnya mencari pekerjaan di masa depan pada profesi yang sama. Faktor-faktor yang mungkin mempengaruhi keputusan untuk melakukan tindakan whistleblowing meliputi tekanan institusi, iklim etika dari manajemen, dukungan dari rekan-rekan dan atasan, kualitas dan keandalan bukti dari kesalahan, tujuan dari kecurangan, rasa takut dan atau marah, tetap menjadi anonymous, penalaran atau perkembangan moral individu, kerugian yang disebabkan oleh kecurangan, kemungkinan merugikan, materialitas dari tindakan, status karyawan dalam organisasi, umur atau jenis kelamin, budaya, persepsi kontrol perilaku, tekanan sosial, sikap terhadap whistleblowing, penghargaan, perlindungan dari pembalasan dan pembalasan (Mesmer Magnus \& Viswesvaran 2005; Park \& Blenkinsipp 2009; Zyglidopoulos \& Fleming 2008; Liyanarachchi \& Newdick 2009; Decker \& Calo 2007; Gundlach, Douglas, \& Martinko 2003; Chiu 2002; Stansbury \& Victor 2009; Bouville 2008; Henik 2008 dalam Kennett, Downs \& Durler 2011). Penelitiaan yang dilakukan Crismastuti (2008) menyatakan potensi akademik mahasiswa berpengaruh pada kecenderungan perilaku curang, di mana semakin tinggi potensi akademik maka akan semakin rendah kecenderungan melakukan perbuatan curang. Penyataan ini didukung oleh Ponnu, Naidu dan Zamri (2008) yang menyatakan bahwa mahasiswa dengan gelar pendidikan tinggi lebih mungkin melakukan tindakan whistleblowing.

\section{Whistleblowing System}

Sistem pelaporan pelanggaran atau whistleblowing system adalah suatu sistem yang dirancang sedemikian rupa mengenai kriteria kecurangan yang dilaporkan yang meliputi $5 \mathrm{~W}+1 \mathrm{H}$, tindak lanjut dari laporan tersebut, reward dan perlindungan bagi sang pelapor atau whistleblower, dan hukuman atau sanksi untuk terlapor. Menurut Zimbelman, Albrecht, Albrecht, \& Albrecht (2006), program whistleblowing yang baik dapat menjadi alat yang sangat efektif dalam mendeteksi dan mencegah kecurangan. Whistleblowing system yang efektif harus memenuhi 4 elemen, pertama anonimitas, merupakan sebuah sistem yang baik harus merahasiakan identitas seorang whistleblower, karena tanpa rasa takut untuk melaporkan tindak pelanggaran dan kecurangan di dalam organisasi. Ketika sebuah laporan tersebut merupakan bagian dari sebuah kejahatan, maka dapat memudahkan untuk menginvestigasi pelanggaran yang dilaporkan. Kedua, independensi, contohnya seorang karyawan akan merasa nyaman jika pelanggaran yang ia laporkan ditindaklanjuti oleh pihak yang independen, artinya tidak ada hubungan dengan pihak organisasi maupun pihak yang melakukan pelanggaran. Ketiga, akses yang mudah, artinya karyawan harus mempunyai beberapa saluran untuk melaporkan tindak pelanggaran. Diantaranya dapat melalui telepon, $e$-mail, sistem online, dan faximile. Hal ini menjamin semua karyawan (dari manajer puncak hingga buruh) bisa dengan merahasiakan namanya untuk melaporkan tindak pelanggaran melalui saluran-saluran tersebut. Terakhir, tindak lanjut, pelanggaran yang terlaporkan melalui whistleblowing system kemudian ditindaklanjuti untuk menentukan tindakan yang diperlukan dalam menyelidiki suatu pelanggaran. Hal ini akan menunjukkan manfaat dari sistem tersebut dan dapat mendorong karyawan untuk lebih aktif lagi melaporkan tindak pelanggaran.

\section{Academic Fraud}

Kecurangan akademik melibatkan usaha yang disengaja untuk melakukan kecurangan. Kecurangan akademis bisa didefinisikan sebagai plagiarisme; fabrikasi atau pemalsuan bukti, data, atau hasil; pemaksaan bukti atau data yang relevan; penyimpangan sumber-sumber yang keliru; pencurian ide; atau penyimpangan yang disengaja dari karya penelitian atau data orang lain. Matindas (2010) menambahkan bahwa kecurangan akademik muncul sebagai interaksi berbagai faktor, baik yang bersifat internal (ada di dalam diri pelaku) maupun yang bersifat eksternal (berasal dari lingkungan). Matindas (2010) menyebutkan bahwa banyak sekali faktor 
yang berkaitan dengan kecurangan akademik. Faktor yang bersifat internal antara lain meliputi academic self-efficacy, indeks prestasi akademik, etos kerja, selfesteem, kemampuan atau kompetensi motivasi akademik (need for approval belief), sikap (attitude), tingkat pendidikan teknik belajar (study skill), dan moralitas. Selain itu, faktor yang bersifat eksternal antara lain meliputi pengawasan oleh pengajar, penerapan peraturan, tanggapan pihak birokrat terhadap kecurangan, perilaku siswa lain serta asal negara pelaku kecurangan.

Tiap tiap faktor yang disebut di atas sesungguhnya adalah faktor yang mungkin terkait satu dengan lainnya. Sebagai contoh, self-esteem (harga diri) boleh jadi berkaitan dengan kompetensi akademik dan komptensi akademik juga berkaitan dengan self-efficacy maupun teknik belajar. Matindas (2010) memaparkan beberapa hal yang mendorong terjadinya kecurangan akademik, antara lain: individu yang bersangkutan tidak tahu bahwa perbuatan tersebut tidak boleh dilakukan, individu yang bersangkutan tahu hal tersebut tidak boleh dilakukan tetapi yakin bahwa individu tersebut dapat melakukannya tanpa ketahuan, individu yang bersangkutan tahu hal tersebut tidak boleh dilakukan serta tidak yakin bahwa perbuatan tersebut tidak akan diketahui, tetapi individu tersebut tidak melihat kemungkinan lain untuk mencapai tujuan utamanya (lulus atau mendapat nilai kredit untuk kenaikan pangkat), individu yang bersangkutan tidak percaya bahwa ancaman sanksi akan benar-benar dilakukan, dan individu yang bersangkutan tidak merasa malu apabila perbuatannya diketahui orang lain.

Colby (2006) menyatakan bahwa di Arizuna State University kategori kecurangan akademik dibagi menjadi lima kategori adalah : (1) Plagiat, (2) Pemalsuan data, misalnya membuat data ilmiah yang merupakan data fiktif, (3) Penggandaan tugas, yakni mengajukan dua karya tulis yang sama pada dua kelas yang berbeda tanpa izin dosen/guru, (4) Menyontek pada saat ujian, (5) Kerja sama yang salah.

Lambert, Hogan dan Barton (2003) menuliskan sama dengan Colby bahwa umumnya ada empat hal yang termasuk kecurangan akademik. (1) menyontek dengan menggunakan materi yang tidak sah dalam ujian, (2) menggunakan informasi, refensi atau data-data palsu, (3) plagiat, (4) membantu siswa lain untuk menyontek seperti membiarkan siswa lain menyalin tugasnya, memberikan kumpulan soal-soal yang sudah diujiankan, mengingat soal ujian kemudian membocorkannya. Anitsal et al. (2009) menuliskan bahwa ada dua kategori kecurangan akademik yaitu kecurangan akademik pasif dan kecurangan akademik aktif. Perilaku kecurangan akademik pasif meliputi melihat orang lain menyontek tapi tidak melaporkannya, memberikan informasi tentang soal ujian kepada orang yang belum ujian di mata pelajaran yang sama. Perilaku kecurangan akademik aktif meliputi perilaku meminta orang lain untuk mengambil soal ujian, menyalin jawaban dari orang lain, dan menggunakan telpon seluler untuk meminta atau mengirimkan jawaban.

\section{Akibat yang Ditimbulkan Kecurangan Akademik}

Mulyawati et al (2010) menyatakan bahwa akibat dari kecurangan akademik: (1) tingkat produktifitas pendidikan di Indonesia sangat rendah, (2) Proses belajar mengajar dalam lembaga pendidikan gagal untuk mendidik generasi muda yang diidamkan. Sistem pendidikan menghasilkan manusia yang tidak jujur (menyontek) yang kemudian menjelma menjadi seorang polisi, guru, dokter, jaksa, pengusaha, hakim, dan profesi lainnya yang bisa lebih melakukan tindak ketidakjujuran yang lebih canggih lagi. memunculkan dalam diri siswa perilaku atau watak yang tidak percaya diri, tidak disiplin, tidak bertanggung jawab, tidak kreatif, tidak berprestasi, tidak mau membaca buku pelajaran tapi siswa lebih rajin membuat catatan-catatan kecil untuk bahan menyontek. Maraknya budaya menyontek merupakan indikasi bahwa sudah tergantikannya budaya disiplin dalam lembaga pendidikan yang dampaknya tidak hanya akan merusak 
integritas dari pendidikan itu sendiri, namun bisa menyebabkan perilaku yang lebih serius seperti tindakan kriminal (Mulyawati et al, 2010). Anitsal et al., (2009) mempertegas pernyataan Mulyawati bahwa memang ada korelasi antara kecurangan akademik dengan perilaku tidak etis.

\section{METODE PENELITIAN}

Pada penelitian ini yang menjadi objek penelitian adalah Whistleblowing System dalam mengurangi fraud akademik. Penelitian ini dilaksanakan dengan pendekatan kualitatif. Responden dalam penelitian ini adalah mahasiswa yang tergabung dalam unit kegiatan yaitu Himpunan Mahasiswa Akuntansi (HIMATANSI) pada lingkungan Perguruan Tinggi yang mempunyai peran dalam organisasi tersebut misalkan dari ketua, sekretaris, bendahara dan anggota Himatansi di lingkungan perguruan tinggi.

Teknik pengumpulan data yang digunakan adalah wawancara, observasi dan dokumentasi. Dalam penelitian ini, analisis data yang digunakan adalah Analisis Data Lapangan Model Miles dan Huberman. Miles dan Huberman (dalam Sugiyono, 2013) mengemukakan bahwa aktivitas dalam analisis data kualitatif dilakukan secara interaktif dan berlangsung secara terus-menerus sampai tuntas, sehingga datanya sudah jenuh. Aktivitas dalam analisis data, yaitu data reduction, data displays, dan conclusion drawing/verification. Dalam teknik pemeriksaan keabsahan data, peneliti menggunakan teknik triangulasi dengan teori. Dimana dalam pengertiannya tri- angulasi adalah teknik pemeriksaan keabsahan data yang memanfaatkan sesuatu yang lain dalam membandingkan hasil wawancara terhadap objek penelitian (Moleong, 2004).

\section{ANALISIS DAN PEMBAHASAN}

Mahasiswa sebagai individu memiliki alasan ketika melakukan kecurangan akademik. Alasan tersebut dipengaruhi dua faktor yakni faktor internal dan faktor eksternal. Faktor eksternal yakni faktor yang melatarbelakangi mahasiswa melakukan kecurangan akademik karena lingkungan dan teman akademik, yang kedua adalah faktor internal karena merasa tidak meniliki kemampuan dalam mengerjakan tugas. Sehingga kedua alasan tersebut dapat mendorong mahasiswa untuk melakukan tindakan kecurangan akademik yang dapat dikategorikan menjadi 5 (lima) kategori yaitu: plagiarisme, pemalsuan data, penggadaan tugas, menyontek saat ujian, dan kerjasama yang salah. Kelima kategori ini dapat dikurangi dengan menerapkan whistleblowing system di lingkungan kampus dengan melibatkan seluruh elemen yang ada di kampus.

\section{Kategori kecurangan akademik dikalangan mahasiswa}

Matindas (2010) dan Lambert et al. (2003) menuliskan sama dengan Colby bahwa umumnya ada empat hal yang termasuk kecurangan akademik. (1) menyontek dengan menggunakan materi yang tidak sah dalam ujian, (2) menggunakan informasi, refensi atau data-data palsu, (3) plagiat, dan (4) membantu siswa lain untuk

Tabel 1.

Responden Penelitian

\begin{tabular}{|c|c|c|c|c|}
\hline No & Narasum ber/inform an & $\begin{array}{l}\text { Je } n \text { is } \\
\text { Ke ela m in }\end{array}$ & Jabatan/Keahlian & $\begin{array}{l}\text { Lama Beror- } \\
\text { ganisasi }\end{array}$ \\
\hline 1 & Nara Sumber 1 & Laki-laki & Ketua Himatansi & 2 Tahun \\
\hline 2 & Nara Sumber 2 & Perempuan & Sekretaris Himatansi & 2 Tahun \\
\hline 3 & Nara Sumber 3 & Perempuan & Bendahara Himatansi & 2 Tahun \\
\hline 4 & Nara Sumber 4 & Perempuan & $\begin{array}{l}\text { Bidang Keilmuan dan } \\
\text { Keislaman }\end{array}$ & 2 Tahun \\
\hline 5 & Nara Sumber 5 & Perempuan & Anggota & 2 Tahun \\
\hline
\end{tabular}


menyontek seperti membiarkan siswa lain menyalin tugasnya, memberikan kumpulan soal-soal yang sudah diujiankan, mengingat soal ujian kemudian membocorkannya. Anitsal et al. (2009) menuliskan bahwa ada dua kategori kecurangan akademik yaitu kecurangan akademik pasif dan kecurangan akademik aktif. Perilaku kecurangan akademik pasif meliputi melihat orang lain menyontek tapi tidak melaporkannya, memberikan informasi tentang soal ujian kepada orang yang belum ujian di mata pelajaran yang sama. Perilaku kecurangan akademik aktif meliputi perilaku meminta orang lain untuk mengambil soal ujian, menyalin jawaban dari orang lain, dan menggunakan telepon seluler untuk meminta atau mengirimkan jawaban. Hasil penelitian yang telah dilakukan diatas menjadikan peneliti tertarik secara langsumg untuk menanyakan contoh kecurangan apa saja yang sering dilakukan oleh mahasiswa, dengan hasil wawancara informan 1, 2, 3, 4, dan 5 memiliki jawaban yang sama dengan yang telah dituliskan oleh peneliti terdahulu yaitu kecurangan saat mengerjakan ujian, plagiat terhadap karya atau pekerjaan dari mahasiswa lain atau tulisan orang lain dan menitip absen/ presensi.

\section{Persepsi Mahasiswa Atas Whistleblowing System}

Elisa (2008) menuliskam bahwa umumnya para siswa merasa bahwa tindakan whistleblowing diperlukan dalam mengungkapkan kasus kecurangan, meskipun mereka cenderung tidak ingin melakukan tindakan whistleblowing karena tingginya resiko seperti pembalasan dan sulitnya mencari pekerjaan di masa depan pada profesi yang sama. Tingginya resiko yang dialami ini menjadi berkurang dengan berlandaskan pada UU 13/2006 tentang Perlindungan Saksi dan Korban. Oleh karena itu persepsi mahasiswa terkait dengan whistleblowing sistem menjadi sangat penting dikarenakan dari persepsi ini bisa diketahui bahwa whistleblowing sistem ini mempunyai benefit dalam mengurangi fraud, hal ini sejalan dengan yang diungkapkan informan 1 dalam wawancara:

$\begin{array}{lr}\text { "menunjukkan } & \text { bahwa } \\ \text { whistleblowing } & \text { system }\end{array}$ diperlukan untuk mengurangi kecurangan akademik dikalangan mahasiswa karena membuat sistem pembelajaran menjadi lebih efektif dan tercipta keadilan diantara mahasiswa"

Sedangkan Informan 2 dalam wawancara menyatakan bahwa:

"whistleblowing sistem merupakan alternatif sistem yang dapat diterapkan untuk mengatasi adanya perbedaan karakter yang dimiliki oleh mahasiswa agar kecurangan akademik yang dilakukan oleh mahasiswa dapat dilaporkan tanpa ada tekanan, ancaman dan rasa tidak aman."

Informan yang ke 3 dan 4 menambahkan:

"mahasiswa menjadi memiliki keberanian untuk mengungkapkan kecurangan yang dilakukan temannya sendiri karena yang terjadi selama ini ada rasa takut pada diri mahasiswa untuk mengungkap kecurangan dikalanagan mahasiswa"

“whistleblowing sistem ini dapat mengurangi perbuatan kecurangan akademik yang sering dilakukan oleh mahasiswa karena apabila diteruskan tanpa ada tindak lanjut maka akan mengakibtakan mahasiswa tersebut terbiasa melakukan tindakan kecurangan sehingga ketika bekerja disebuah perusahaan akan melakukan tindakan kecurangan seperti manipulasi laporan keuangan"

Informan yang ke 5 memberikan jawaban yang dapat melengkapi jawaban informan sebelumnya, yaitu:

"sebagai alat pengendali yang dapat mengurangi kecurangan akademik yang terjdi dan efek jangka panjang dari penerapan sistem ini adalah Universitas mendapatkan pengakuan yang baik oleh masyarakat serta mendapatkan 
penghargaan terkait dengan pembangunan karakter yang menjauhkan mahasiswa dari sifat melakukan tindakan kecurangan".

Beberapa jawaban di atas dapat menunjukkan bahwa whistleblowing sistem ini mempunyai beberapa alasan yang positif apabila diterapkan. Namun pengungkapan ini bisa terwujud apabila ada budaya positif yang dibangun oleh kampus sehingga memunculkan niat untuk mengurangi kecurangan akademik, seperti yang dituliskan oleh Sulistomo (2012) bahwa perspesi tentang norma subyektif, sikap, dan persepsi tentang kontrol perilaku berpengaruh signifikan positif terhadap niat mahasiswa akuntansi melakukan pengungkapan kecurangan. Hal yang sama dituliskan oleh Hwang et al (2008) yang memiliku tujuan untuk mengetahui akibat dari culture pada niat akuntan dan auditor professional saat ini dan dimasa yang akan datang untuk menjadi wh istle blower pada sosial budaya Cina dengan hasil bahwa makna moralitas secara umum adalah faktor terpenting untuk mendorong whistleblowing, dengan menuruti aturan organisasi mereka.

\section{Peranan mahasiswa dalam whistleblowing system}

Penelitian Arista (2015) mengatakan bahwa plagiarime yang terjadi di lingkungan mahasiswa dikarenakan adanya budaya dosen dalam mengajar, akses informasi yang mudah, kurangnya pengetahuan tentang plagiarisme, kurangnya monitoring, bertujuan mencari nilai dan IPK, serta faktor ekonomi. Sedangkan menurut Zainur (2012) plagiarisme terjadi dikarenakan adanya perkembangan teknologi dan beban tugas dari dosen. Kondisi-kondsi yang telah dicontohkan tersebut memberikan gambaran bahwa perilaku kecurangan yang dilakukan oleh mahasiswa disebabkan oleh beberapa sebab sehingga diperlukan bantuan mahasiswa untuk melakukan pengungkapan kecurangan akademik yang dilakukan oleh mahasiswa. Pengungkapan tersebut diawali dengan adanya niat akan tetapi terkadang niat tersebut sudah ada namun terbentur dengan adanya rasa takut dan tidak aman sehingga diperlukan jaminan keamanan dan kerahasiaan. Jaminan tersebut dapat dibangun dengan setiap fakultas membuat sistem terkait dengan whistleblower dan mengacu pada UU 13/2006 tentang Perlindungan Saksi dan Korban. Sehingga peranan mahasiswa menjadi penting untuk pengungkapan kecurangan akademik karena mahasiswa mendapatkan jaminan keamanan dan dibawah ini hasil wawancara dengan mahasiwa terkait sejauh mana peranan mahaisiswa tersebut. Hasil wawancara informan 1;

"mahasiswa memberikan sosialisasi akan pentingnya manfaat dari whistleblowing sistem, kemudian akan melaporkan apabila menemukan situasi yang mengarah kepada tindakan kecurangan akademik."

"yang adil terkait dengan nilai yang didapat mahasiswa karena mahasiswa yang jujur terkadang merasa diberlakukan tidak adil oleh mahasiswa yang berlaku curang dengan melakukan menyontek."

\section{Tahapan Proses Whistleblowing System}

Sistem pelaporan pelanggaran atau whistleblowing system adalah suatu sistem yang dirancang sedemikian rupa mengenai kriteria kecurangan yang dilaporkan yang meliputi $5 \mathrm{~W}+1 \mathrm{H}$, tindak lanjut dari laporan tersebut, reward dan perlindungan bagi sang pelapor atau whistleblower, dan hukuman atau sanksi untuk terlapor. Menurut Zimbelman (2006), program whistleblowing yang baik dapat menjadi alat yang sangat efektif dalam mendeteksi dan mencegah kecurangan, dengan kriteria memenuhi empat elemen yaitu anominitas (kerahasiaan pelapor), independensi, akses yang mudah, dan tindak lanjut. Berikut beberapa pendapat mahasiswa terkait dengan tahapan tersebut:

Informan 1 dan 2 memiliki karakteristik jawaban yang sama:

"Sistem whistelblowing yang diterapkan harus memiliki tahapan proses kerja yang tersistematis 
agar setiap ada laporan yang masuk dari pelapor ada tindak lanjut sehingga akan diketahui keberlanjutan dari laporan yang masuk apakah laporan tersebut memang merupakan laporan yang mengindikasi kecurangan atau sebaliknya maka pihak yang melakukan kecurangan tersebut dapat berubah perilaku menjadi lebih baik atau beretika."

Informan 3 menambahkan diperlukan peranan dosen dalam proses kerja sistem ini

"Sistem whistelblowing yang diterapkan harus memiliki tahapan proses kerja dengan melibatkan dosen dalam tahapan proses kerja agar sistem dapat berjalan secara optimal,"

Informan 4 dan 5 lebih mengarah kepada hasil luaran dari sistem ini perlu pembuktian

"Sistem whistelblowing yang diterapkan harus memiliki tahapan proses kerja kaerena sistem ini masih baru sehingga butuh penyesuaian dan pembuktian sistematika dalam menjalankannya."

Tahapan-tahapan yang dilakukan dari sistem whistleblowing ini dari adanya laporan, kemudiaan pihak kampus memberikan tindak lanjut maka menurut mahasiswa baik informan $1,2,3,4$, dan 5 memberikan kesimpulan yaitu:

"Evaluasi diperlukan dalam sistem whistleblowing dikarenakan sistem yang berjalan akan menghasilkan kinerja yang optimal apabila ada evaluasi sehingga setiap evaluasi yang ada memberikan solusi yang efektif dan kekurangan dari sistem yang dibangun dapat diperbaiki."

\section{SIMPULAN}

Hasil dari penelitian ini adalah kecurangan yang terjadi dapat dikurangi dengan menerapkan whistleblowing sistem, karena whistleblowing sistem ini mempunyai banyak manfaat seperti kondisi kampus menjadi lebih kondusif dan kualitas pembelajaran menjadi lebih baik. Hal ini menyebabkan output yang dihasilkan juga lebih baik serta meningkatkan kepatuhan mahasiswa terhadap peraturan yang diberlakukan di lingkungan kampus. Persepsi mahasiswa mengenai sistem whistleblowing dapat diterapkan ketika ada: (1) peranan mahasiswa dalam melaporkan tindakan kecurangan yang terjadi di kampus, (2) peranan mahasiswa membantu dalam proses sosialisasi akan pentingnya whistleblowing sistem, (3) melaporkan apabila menemukan situasi yang mengarah kepada tindakan kecurangan akademik dan (4) membantu dalam proses pemantauan apakah sistem ini berjalan. Hasil penelitian ini sesuai dengan penelitian yang dilakukan oleh Lambert et al. (2003) dan Matindas (2010).

Sistem whistleblowing ini dapat diterapkan ketika ada peranan dari mahasiswa untuk melaporkan tindakan kecurangan yang terjadi di lingkungan kampus. Peran mahasiswa adalah membantu dalam proses sosialisasi tentang pentingnya manfaat dari whistleblowing system, melaporkan apabila menemukan situasi yang mengarah kepada tindakan kecurangan akademik dan memantau apakah sistem ini berjalan.

\section{KETERBATASAN DAN SARAN \\ Keterbatasan}

Keterbatasan dalam penelitian ini adalah lokasi penelitian hanya satu fakultas saja, karenanya dilihat dari segi generalisasi masih lemah. Selain itu, penelitian ini menggunakan pendekatan kualitatif dengan teknik wawancara yang hasilnya tidak bisa dilihat secara prosentase. Terakhir penelitian ini tidak melibatkan dosen, dekan, dan rektor sebagai responden.

\section{Saran}

Saran untuk penelitian selanjutnya adalah perlu menambah objek penelitian menjadi lebih dari satu fakultas baik fakultas yang sosial humoniora, sastra dan eksak agar hasil penelitian bisa digeneralisasikan lebih luas. Selanjutnya, sebaiknya penelitian yang akan datang tidak hanya wawancara akan tetapi menambah dengan kuesioner dan melibatkan dosen, dekan dan rektor sebagai responden. 


\section{DAFTAR PUSTAKA}

Anitsal, I., Anitsal, M.M., \& Elmore, R. (2009). Academic dishonesty and intention to cheat: A model on active versus passive academic dishonesty as perceived by business student. Academic of Educational Leadership Journal, 13 (2), 17-26.

Arista, R.F. (2015). Plagiarisme di kalangan mahasiswa. Paradigma Jurnal Online Mahasiswa, 3 (2). Diakses dari http:// jurnalmahasiswa.unesa.ac.id.

Bouville, M. (2008). Whistleblowing and morality. Journal of Business Ethics, 81, 579-585.

Chiu, R.K. (2002). Ethical judgment, locus of control, and whistleblowing intention: A case sSudy of mainland chinese MBA students. Managerial Auditing Journal, 17 (9), 581-587.

Crismastuti, A.A. (2008). Faktor- Faktor yang Mempengaruhi Kecurangan Akademik Mahasiswa. Semarang: Pusat Pengkajian dan Pengembangan Akuntansi Universitas Katolik Soegijapranata.

Colby, B. (2006). Cheating; What is it. Diakses 20 Desember 2016, dari http:// clas.asu.edu /files/AI\%20Flier.pdf.

Decker, W., \& Calo, T. (2007). Observers impressions of unethical persons and whistleblower. Journal of Business Ethics, 76, 309-318.

Elias, R. (2008). Auditing students' proffesional commitment and anticipatory socialization and their relationship to whistleblowing. Managerial Auditing Jornal, 23(3), 283-294.

Gundlach, M.J., Douglas, S.C., \& Martinko, M.J. (2003). The decision to blow the whistle : A social information processing framework. Academy of Management Review, 28 (1), 107-123.

Hwang, D., Staley, B., Te Chen, Y., \& Lan, J. S. (2008). Confucian culture and whistleblowing by professional accountans: An exploratory study. Managerial Auditing Journal, 23(5), 504-526.

Kennett, D., Downs, A., \& Durler, M.G. (2011). Accounting students intent to blow the whistle on corporate fraudulent financial reporting : An experiment. International Journal of Business and Social Science, 2(14), 14-23.

Lambert, E.G., Hogan, N.L. \& Barton, S.M. (2003). Collegiate academic dishonesty : What have they done, how often have they done It, who does it, and why did they do it, 7(4), 1-27.

Liyanarachchi \& Newdick, C. (2009). The impact of moral reasoning on whistleblowing : New zealand evidance. Journal of Business Ethics, 89(1), 3757.

LPSK. (2011). Memahami Whistleblower. Jakarta : LPSK.

Mamoer, A. M. et al.. (2007). Modul whistleblowing system. Diakses 20 Desember 2016 dari http://www.kadinindonesia.or.id/emn/images/ dokumen/KADIN-107-234503122007.pdf.

Matindas, R. (2016, 21 Desember). Mencegah kecurangan akademik. Diakses 21 Desember 2016 dari http://

budimatindas.blogspot.com/2010/08/ mencegah-kecurangan akademik.html.

Mesmer-Magnus \& Viswesvaran, C. (2005). Whistleblowing in organizations : An examination of correlates of whistleblowing intentions, actions, and retalition. Journal of Business Ethics, 62 (3), 277-297.

Moleong, L.J. (2004). Metode Penelitian Kualitatif. Bandung: Remaja Rosdakarya.

Mulyawati, H., Masturoh, I., Anwaruddin, I., Mulyati, L., Agustendi, S., \& Tartila,. T.S.S. (2010). Pembelajaran Studi Sosial. Bandung : Alfabeta.

Mustapha, M., \& Siaw, L.S. (2012). Whistle Blowing: Perceptions of future accountants. International Conference on Economics Business Inovation, 38, 135-139.

Park, H., \& Blenkinsopp, J. (2009). Whistleblowing as panned behavior survey of South Korean police officers. Journal of Business Ethics, 85(4), 545556.

Ponnu, C.H., Naidu, K., \& Zamri, W. (2008). Determinants of whistleblowing. International Review of Business Research Papers, 4(1), 276-298.

Stansbury, J., \& Victor, B. 2009. Whistleblowing Among Young Employees : A Life Course Perpective. Journal of Business Ethics, Vol. 85(3), 281-299.

Sugiyono. (2013). Metode Penelitian Kuantitatif, Kualitatif R\&D. Bandung: Alfabeta.

Sulistomo, A. (2012). Persepsi mahasiswa akuntansi terhadap pengungkapan kecurangan (Skripsi). Universitas Diponegoro, Fakultas Ekonomi dan Bisnis, Semarang. 
JURNAL AKUNTANSI DAN BISNIS|Vol. 17, No. 1, Februari 2017: 1 - 12

Zainur, M. (2012). Plagiarisme di kalangan mahasiswa dalam membuat tugastugas perkuliahan pada fakultas tarbiyah IAIN Imam Bonjol Padang. Jurnal Al-Ta'lim, 19(1), 5-66.

Zhang, J., Chiu, C.R., \& Wei, L. (2009). On whistleblowing judgement an intention. Journal of Managerial Psychology, 24(7), 627-649.

Zimbelman, M., Albrecht, W.S., Albrecht, C.O., \& Albrecht, C.C., (2006). Fraud Examination, ( $3^{\text {rd }}$ Ed). Mason: SouthWestern Cengage Learning

Zyglidopoulos \& Fleming, P.J. (2008). Ethical distance in corrupt firms : How do innocent bystanders become guilty perpetrators?. Journal of Business Ethics, 78(1), 265 - 274.

Undang-Undang Nomor 13 Tahun 2006 Perlindungan Saksi dan Korban.
Lembaran Negara Republik Indonesia Tahun 2006 Nomor 64. Jakarta.

Keputusan Menteri Keuangan Nomor 103/ PMK.09/2010 Tata Cara Pengelolaan dan Tindak Lanjut Pelaporan Pelanggaran (Whistleblowing) di Lingkungan Kementerian Keuangan. Kementrian Keuangan Republik Indonesia. Jakarta.

Keputusan Menteri Keuangan Nomor 149/ KMK.09/2011 Tata Cara Pengelolaan dan Tindak Lanjut Pelaporan Pelanggaran (Whistleblowing) Serta Tata Cara Pelaporan dan Publikasi Pelaksanaan Pengelolaan Pelaporan Pelanggaran (Whistleblowing) di Lingkungan Kementerian Keuangan. Kementrian Keuangan Republik Indonesia. Jakarta. 